\title{
Financial Management Challenges Facing Implementation of Free Day Secondary Education in Imenti North District, Kenya
}

\author{
Mercy Kaguri, Ibuathu Charles Njati, Kubaison S. Thiaine. \\ School of Business and Economics Meru University of Science and Technology P.O Box 972-60200 Meru \\ Department of Economics School of Business and Economics Meru University of Science and Technology P.O \\ Box 972-60200 Meru \\ Department of Business Management School of Business and Economics Meru University of Science and \\ Technology P.O Box 972-60200 Meru
}

\begin{abstract}
Almost all modern organizations, including schools have the characteristics of the five basic functions performed by all managers which are planning, organizing, commanding, coordinating and controlling. Due to low transition rate of students from primary to secondary school, the government of Kenya launched Free Secondary Education (FSE) initiative strategy in 2008 with an aim of increasing the transition percentage rate through retention and completion without any discrimination. financial management in Kenya's public secondary schools is a very sensitive managerial role, since a lot of tax payer's money is invested in education. This study was carried out in Imenti North District which is in Meru County, Kenya which sought to address financial planning, reports and control challenges that need to be corrected in order to have an improved and sustainable FSE program. The sampling design adopted was simple random sampling. Questionnaires were used as instrument for collecting data from the BOGs and PTAs while interview schedules were administered to the principals, DEO and ZQASOs. Validity of the instruments was done through expert researchers. Reliability was tested through the use of Spearman Brown Prophecy Formula. Target population was 730 with a sample size of 250 participants. Data collected shows that in financial planning; budgeting is often done in either a caress fashion or not done at all with minimal involvement of education stakeholders in the budgetary process, financial reports are poorly prepared while Auditing is done in an arbitrary way. Therefore for financial management to be successful, then planning and controlling should be interdependently linked. The researcher recommends that there is need for improvement of policy tracking of resources to ensure proper, adequate and accountable utilization of resources budgeted for education in the right manner which can be done through external auditing or outsourcing of the services.
\end{abstract}

Key words: financial management, administration, accountability and budgeting.

\subsection{Background information}

\section{Introduction}

Management of any organization is a continuous process involving a chain of command, equity, efficiency, stability and the allocation of authority through the design of 14 principles of management. Of the 14 principles, the following are applicable for school managers in Kenya; division of labour, authority, discipline, unity of command, order and equity. According to Hoy\& Miskel (2008) tasks in most organizations including schools are too complex to be performed by a single individual; division of labour among positions improves efficiency. Efficiency increases because division of labour produces specialization, which in turn leads to employees who become knowledgeable and expert at performing their prescribed duties. Such division enables the organization to employ personnel on the basis of technical qualifications. Hence, division of labour and specialization produce more expertise in school personnel. Hierarchy is perhaps the most pervasive characteristic in modern organizations. Almost without exception, large organizations develop a wellestablished system of super-ordination and subordination, which attempts to guarantee the disciplined compliance to directives from superiors that, is necessary for implementing the various tasks functions of an organization.

Barasa (2009) laments that the public education system in Kenya is structured along the lines of Weber's concept of Hierarchy. There is for instance a DEO who is answerable to the provincial Director of education who in turn is accountable to the Director of education. In secondary schools authority follows downwards where there is the head teacher/principal and immediately under him/her is the deputy head teacher/principal. Answerable to the deputy are various departmental heads. The heads of departments are in turn in charge of subjects teachers.

A school's financial management is the execution by a person in a position of authority of those management actions (regulated tasks) connected with the financial aspects of schools and having the sole purpose of achieving effective education" (Similarly, Joubert and Bray (2007) describe a school's financial 
management as the performance of management actions connected with the financial aspects of a school for the achievement of effective education. The common factor in these definitions of financial management is that a connection is made between the management tasks and the financial aspects of a school. The implication is that the management of school finances involves the task of planning (budgeting), organizing (coordinating), leading (communicating and motivating), as well as controlling (auditing) (Clarke 2007).

The above authors are also in accord that a school's financial management is imperative because it enables the school to achieve effective education properly at the schools under it. It is obligatory for principals to ensure accountability and prudence in the utilization of school funds. Principals are appointed on the basis of their teaching experience, as well as their academic and professional qualifications. Training in or even having a working knowledge of financial management is not considered a prerequisite for appointment to the position of principal which tends to affect them in performing financial management duties. Consequently, principals are lacking the necessary management skills and specifically financial management skills.

The mismanagement of funds by principals often leads to shortage of critical resources in schools as money is not available for the purchasing of the necessary books, equipment and so forth. The planning of school finances usually begins with the drafting of a budget. Where budgeting is an ongoing and dynamic process that is typically marked by regular phases, such as, planning, needs assessment and priority setting. Budgeting is a forward-looking process which should be guided by the school's vision for the future and a realistic assessment of the risks (Clarke 2007; Du Preez et al. 2003).

Budget's purpose can be summarized as assisting systematic planning; quantifying objectives and identifying priorities; coordinating activities and communicating plans within the organization; motivating and increasing the accountability of middle management; authorizing expenditure and activities; controlling, monitoring and analyzing expenditure; and evaluating performance. In an education organization, its financial management activity means bringing all possible input from staff, parents, students and the community together to render the service of quality education. In this respect, organizing of school finances should include aspects such as drawing up a school financial policy; setting up a structure within the school to handle administrative and financial matters; delegating certain functions to clerks, class teachers and the treasurer; and coordinating activities (Kruger 2005; Ntseto 2009). The financial planning of school finances and its control are interdependent and closely linked with each other as note $d$ by Ntseto (2009). It can be deduced that the same relationship exists between the budget and control since a budget is a planning instrument.

World Conference at Jomtien, Thailand in 1990 discussed that developing countries would need to define their priorities for external funding more carefully while relying more on their own resources. According to a study by Digurmati (2009) about Quality Education he found out that Sub-Saharan Africa would require particular support from the World community without which Education For All would remain out of reach for most African countries, in relation to that, A 2010 World Bank study established that the development of postprimary education in Africa would require substantial amounts of external aid to plug current funding.

The school principal, as human resources personnel has numerous areas to effectively and adequately manage if he is to be successful. He has to manage the school environment in such a way that it will be conducive for teaching and learning to take place and achieve the set educational goals and objectives. Furthermore, for the job of the principal to be effective, he needs finance to run the affairs of the school.

For him to be effective, to manage the students as well as physical facilities, teaching aids, invite resources persons in some areas, sell the school's programs and ideas to the public he needs money/funds. No one can disputes the fact that money answers "all" things. Fund is required to maintain school plant and other services that will keep the school going. The school manager needs money to carry out all round maintenance of the school properties, organize in-service training, seminars and also provide other essentials that will make teaching and learning to be effective. Every school list their programs yet these programs can only be implemented where there is finance. Without finance, school managers cannot meet up their responsibilities. Although public schools are being funded by the government throughout the country, but because of the inadequacy in the funding system, school administrators generate funds from other sources such as alumni association, donations et cetera to supplement whatever government is giving them. Though students pay school fees and PTA levies in public schools but what they pay is just too small compare to the services that is rendered and the means of rendering this services. According to the FSE policy, the government is expected to meet the tuition fees of ksh. 10,265 per student, while the parents are responsible for provision of uniforms, boarding fees, school meals and transport of their children. However, there have been series of allegations levied against school administrators in the area of money management in such a way that school administrators are accused of mismanaging and embezzling money put in their custody. Therefore this study sought to discard or concur with such claims.

There are a lot of challenges facing education in Nigeria and making it difficult for good quality education that is capable of bringing about sustainable development. The first and perhaps the greatest challenge facing education is inadequate funding by federal, states and local governments, to the extent that funding has 
been in response to conditional ties imposed by international financial institutions (IFIs). Statistics show that federal government expenditure on education between 1997 and 2000 has been below $10 \%$ of overall expenditure, which is low in relation to the UNESCO recommendation of $26 \%$ of national budgets. In Kenya, education sector takes up about $21 \%$ of the government annual expenditure accounting for the second largest share of the annual budget Ministry Of Finance spending plans for 2012/2013 (The Daily Nation Newspaper, June $15^{\text {th }}$ 2012). This is further distributed as follows Teacher's salaries $50.92 \%$, FDSE $8.45 \%$, FPE $3.56 \%$, ECD $0.69 \%$ and others inclusive of Research $36.38 \%$ (The Daily Nation Newspaper, June $15^{\text {th }} 2012$ ). It is viewed that $8.45 \%$ is very low compared to the expected outcome in the FSE, in reference to teaching and learning resources for secondary education which include laboratories which are not required in the other sectors which are mentioned here. This amount needs to be planned and controlled to meet the set educational goals and objectives.

Imenti North District is in former Eastern province in Kenya. It borders Meru Central, Buuri, Tigania West, Isiolo and Tharaka within the latitude $0^{\circ} 3$ ' $45^{\prime}$ ' North and $0^{\circ} 2^{\prime} 30^{\prime \prime}$ 'South and latitudes $37^{\circ}$ and $38^{\circ}$ East. (G.O.K, 2012). It comprises two divisions: Miriga Mieru West (MMW) and Miriga Mieru East (MME) covering an area of $223659 \mathrm{~km}^{2}$ (C.B.S,2009). The district has a population of 149,144 people. The district has 40 secondary schools of which 26 are day secondary schools established through constituency development fund.

\subsection{Statement of the problem}

Financial management in Kenya's public secondary schools is a very sensitive managerial role, since a lot of tax payers' money is invested in education. Each of them therefore would like to see prudent management of such funds so that the intended goals of education and institutional objectives are achieved optimally. But this is not the case because the school managers who are entrusted with these funds are always faced with many challenges. So much has been said by the public on poor management of financial resources in schools which mainly lead to having school facilities being run down. Bearing in mind that; the aim of education in Kenya is national development. In an effort to enhance accessibility, equity and retention after FPE initiative of 2003, FSE was introduced by the government in 2008. The government and other education stakeholders have continued to give their support for the realization of FSE initiative. However, the 95\% transition rate from primary to secondary school has not been achieved according to reports by MOE (2012) gross enrolment rates have been $60.19 \%$ in 2009 and $90 \%$ in 2012 while in Imenti North district enrolment stands at $83.3 \%$. The ways these programs are implemented may differ greatly across schools depending on the government expectations, students' needs and how the managers carry out the program implementation. A manager's role of management may be affected by a variety of factors among them the school size, the district size and geographical location: rural or urban, social-class background of the children attending the school. The planning of funds available, financial reports and financial controls are significant factors towards effective implementation of FDSE. However, concerns have been raised over an effective implementation of the program and whether it could be a reality. This study therefore sought to find out why $95 \%$ transition rate had not been achieved even after introduction of FDSE. This study sought to address financial management challenges facing implementation of FSE amongst day secondary schools in Imenti North District, Meru County, Kenya, through a close examination of the administration of the program and suggest possible solutions.

\subsection{Purpose of the Study}

The purpose of this study was to investigate the financial management challenges facing implementation of free secondary education in regard to financial planning, financial reports and finally financial controls, specifically as regards their capacity for fund sourcing, capacity for school budgeting and financial control. It was also to interest of emphasizing the ability of school managers in utilizing available funds for the achievement of the education goals and objectives at the school level.

\subsection{Objectives of the Study General Objective:}

The general objective of this study was to investigate financial management challenges facing implementation of FDSE program; and to evaluate their effectiveness in meeting requirements of the educational goals and aims, particularly in Imenti North District, Meru County Kenya.

\section{Specific Objectives}

The study was guided by the following specific objectives:

1. To find out the role of financial planning in implementation of Free Day Secondary Education in Imenti North District.

2. To assess the input of financial reports on implementation of Free Day Secondary Education amongst day schools in Imenti North district. 
3. To establish financial controls input on implementation of Free Day Secondary Education in Imenti North District.

\subsection{Research Questions}

The researcher sought to answer the following research questions.

1. In what ways does financial planning influence effective implementations of Free Day Secondary Education in Imenti North District?

2. What are the financial reports input in implementation of Free Day Secondary Education in Imenti North District?

3. To what extent do financial controls influence implementation of Free Day Secondary Education in Imenti North District?

\subsection{Significance of the study}

The findings of this study may provide valuable insights to the government, MOE planners, School Principals, school boards of governors, development partners, CDF committee and the communities on the effects and challenges likely to be encountered during the effective implementation of FDSE initiative. Data presented to the MOE may help in laying strategies of effective FDSE implementation and FDSE sustainability. The government is likely to be in a position to devise strategies to improve the managerial skills of school principals in order to be more effective in the implementation of the program.

To the principals and teachers the findings can act as a self assessment tool. To the school boards of governors, study findings may help them to devise strategies to improve on their managerial duties and functions. The study is also likely to help QASOs during their visit to schools to give proper guidance to the school managers on the best practice approaches of handling the emerging challenges while implementing the FSE program. Study findings may help donors and other well wishers in establishing the ways of improving the program. The data collected will add on the body of knowledge of secondary education financial management and education change management besides filling gaps in research which can provoke other researchers to do similar studies in other regions or levels of education.

\subsection{Limitations and Delimitation (Scope) of the study}

The study was carried out in Imenti North District, Meru County, Kenya. It addressed management challenges that are being faced in efforts to effective implementation of FDSE in relation to financial planning, financial reports/statements and financial controls. The study delimited itself on day secondary schools because the tuition waiver for secondary education is always remitted as FDSE funds and not FSE and the challenges were as unique as the categories themselves. Eight principals, one hundred and three BOG members, eighty six PTA members participated in the study, Imenti North District DEO, 2ZQASOs from MMW and MME were also included. Questionnaires were used to collect data from BOG and PTA members, while to the principals, DEO and ZQASOs interview schedules were administered.

There was a variation of management expertise based on experience, training, and management skills which were difficult to investigate and generalize to all educational managers where each individual was to be treated unique. Therefore the sample findings of this study cannot be used for generalization of the whole country. The human social aspects of educational managers is broadly conceived such that there were other intervening variables like government policies, born leaders, made leaders and other educational stakeholders which influence FDSE implementation and therefore might have influenced the findings hence limiting the study. Some parents were not conversant with school policies due to literacy levels. In some schools, some members of management committees cannot spell their names correctly because there was collusion during their appointment.

\subsection{Assumptions of the Study}

The study was based on the following assumptions. That;

School budgets were poorly drawn to implement and run the free day secondary education program smoothly, financial management government policies and guidelines would remain constant throughout the research period for consistency and information collected would be precise, clear and true to the best knowledge of the respondent.

\subsection{Definition of terms/Operationalization of terms}

Effectiveness; this is the measure of how well financial management will contribute to achieving educational goals and objectives

Efficiency; refers to a measure of the expected performance (output) for each unit invested.

Financial control; refers to monitoring actual performance and comparing with target performance. 
Financial management; is the process that involves planning, preparation of financial reports and budget control.

Financial reports; refers to financial statement of the transactions which are reported to the stakeholders.

\subsection{Summary}

This chapter presented the background to the study on financial management by giving a brief explanation on the various definitions and applicability of its concepts and principles in secondary schools. Financial management is addressed in terms of planning, reports and control of budgets which were used to state the research objectives and questions.

\subsection{Introduction}

\section{Review Of Related Literature}

This chapter presents literature review related to the study. The chapter will first cover literature on the status of secondary education in Kenya. Literature will be reviewed on financial management challenges related to introduction of free secondary education which include financial planning, financial reports, and financial controls. After reviewing financial management challenges, the chapter will also present theoretical and conceptual framework, and finally summary of the chapter.

\subsubsection{Status of Secondary Education in Kenya}

Kenya spends more than most African countries on education when expenditure is expressed as a percentage of Gross Domestic Product. (Republic of Kenya, 1999) as a proportion of discretionary expenditures, education spending in Kenya, at 35\%, are higher than almost all other comparable countries except Ghana. Government faces a difficult set of policy and planning choices both at the meso level of sectoral resource allocation and at the micro level of school programme performance. Total government expenditure continues to decline as the share of government expenditure in Gross Domestic Product continues to be reduced. So, there will be downward pressure on resources allocated to education.

The education sector in Kenya has been in the spotlight in the recent past especially during the era of cost sharing which immediately preceded the FPE era. Consumers have been demanding quality services and expecting good returns on their investments in education. Although other forms of technology may be used to enhance the learning process, the direct personal contact between teachers and students remain the most effective tool in the educational process. Thus teacher demand and supply is a central concern of educational planners. Bururia (2010) found out that when secondary education is made free, transition from primary to secondary is enhanced and enrolment of students is increased. However, there is likelihood of education quality being compromised if all other factors are not adequately addressed hence justification of this study.

Glassman \& Sullivan (2008) reported that each secondary school has a PTA, which monitors school performance, raises funds to supplement the school budget, and participates in decisions on the use of these funds. An elected PTA executive committee member is the liaison to the BOG. In practice however, the two bodies are in conflict. The school head is directly accountable to the DEO and the BOG and reports to the PTAs especially on the use of its resources. Lack of documentation limits the ability of PTAs to monitor finances, to understand how money is spent, and to approach the education authorities.

According to the MOE report released in 2010 it notes that with introduction of FDSE in 2008, there was huge expansion of secondary schools which necessitated the demand for more buildings, equipment, supplies and teachers. It means also more funds to be allocated for those resources, but there is shortage of funds. The government subsidy only catering for tuition is not enough to build school physical facilities. Therefore there is need for charging of extra fee to cater for construction and development of these physical facilities. The rising number of students in these schools is placing a heavy burden on the limited teaching staff. The limited schools facilities are poor and do not adequately meet the needs and standards by the MOE for students. There is also the problem of the centralization of educational facilities and this can easily cause a problem of lack of locally produced higher work-force. The facilities, especially libraries, laboratories, furniture and textbooks in most institutions are inadequate. Currently the greatest share of the education budget is met by the government in all public secondary schools. In these schools, the principal is given the responsibility for the control and management of the financial resources of the school and he or she is accountable of all the expenditures for he or she is the one who authorizes payment.

\subsubsection{Financial Management Challenges Related to Introduction of Free Secondary Education}

This study sought to find out financial management challenges facing educational managers of FDSE implementation in Imenti North District, Meru County, Kenya. The challenges could be related to financial planning, financial reports and financial controls. Some of the expected challenges are discussed in the next sub headings. 


\subsubsection{Challenges Related to financial planning}

Barasa (2009) recognizes that efficient management of financial resources is an important task for head teachers. Without adequate financial resources, institutions cannot carry out their defined tasks effectively. Money must be available to run the different departments of the school. The available funds will be used to purchase the required teaching and learning apparatus such as chalks, textbooks, paying of the support staff and building and improvement of infrastructures.

Financial management in education is concerned with the cost of education, sources of income to meet the educational costs and the spending of the income in an objective manner in order to achieve the educational objectives (Okumbe, 2001). However, educational managers are being challenged to justify their financial requests in terms of educational programs rather than the costs, if education has to compete equitably for public funds (Okumbe, 2001). In the preparation of the budget, the principal or head teacher must seek the cooperation of the BOG, the parents, the teachers and other school employees. By enlisting the cooperation of these people, the principal ensures a comprehensive view of the budget and a feeling of partnership which contributes to the much needed espirit de corps (Okumbe, 2001). Since introduction of FDSE government has been providing tuition fees for students while parents or guardians are still required to meet the costs of examination fee for form four examination (KCSE), lunch, school uniforms, transport and infrastructural developments. However, this does not restrict schools from engaging in income generating activities to enable them in having supplementary sources of income necessary for their daily financial commitments. To facilitate proper custody, control and safekeeping of the hinds from various sources, it is a requirement for schools to maintain separate bank accounts for funds from different sources like income generating activities and donor funds. The money that is remitted by the MOE must have a separate bank account from those holding monies from other sources. Studies have found out that financial planning of FDSE funds is in a crisis; therefore this study sought to justify such claims.

Financial planning involves aspects of accounting which involves the overall process of identifying, measuring, recording, interpreting and communicating the results of economic activity; tracking business income and expenses and using these measurements to answer specific questions about the financial and tax status of the business which is basically a system that provides quantitative information about finances. Cole \&Kelly (2011) define planning as the formalization of what is intended to happen at some tie in the future; concerns actions taken prior to an event, typically formulating goals and objectives and then arranging for resources to be provided in order to achieve a desired outcome. Planning leads to budgeting which is a statement usually expressed in financial terms, of the desired performance of an organization (in this case a school) in the pursuit of its objectives over a specified period. A budget is an action plan for the immediate future, representing the operational and tactical end of the corporate planning chain. Cole \& Kelly further states that managers responsible for carrying out budgets should participate in their formulation, and should be flexible to be changed if conditions arise, and budgets should be seen as means to an end, and not and end in themselves.

\subsubsection{Challenges Related to Financial reports}

Financial reports usually need accounting and its products such as an organization's annual report as a platform upon which to build many decisions and activities. Organizations must follow specific rules and formats of presentation for their annual reports and financial statements. The key accounting event for any organization is the publication of the annual report which records the financial performance over a book year. Financial reports help managers to discuss results and spending and performance against budget, they usually work from management reports, which have been prepared by the school accountants using accounting information systems. Such reports show budgeted revenues and costs for the period or year to date, actual revenue and costs to date and the variances between them. Cole \& Kelly (2011) in their study established that organizations may create and adopt a number of statements to communicate the corporation's view on the subject of ethics. They stipulated common issues in business ethics to be included are accountability (transparency and reporting) business conduct (compliance with the law, competitive conduct, and corruption and bribery conflicts of interest. The existence of a code of practice in ethics, supported by senior management and made a natural feature of a company's culture, will enable better distinctions to be made between what is acceptable business practice and what is sharp practice. It has often been said that leadership by example is the most effective way to improve business ethics. Leaders must therefore be honest and trustworthy with high integrity (even though this is not measurable). To be perceived as an ethical leader, it is not enough to just be an ethical person. An executive ethical leader must also find ways to focus the organization's attention on ethics and values and to infuse the organization with principles that will guide the actions of all employees.

Deegan \& Unerman (2011) at the core of the accounting process is an expectation that accountants should be objective and free from bias when performing their duties. The information being generated should represent faithfully the underlying transactions and events and it should be neutral and complete. However, can we really accept that accounting can be 'neutral' or 'objective? Under considerations of economic and social 
consequences prior to the release of an accounting preparation and presentation of financial statements? In these countries, if the economic or social implications of a particular accounting standard have been deemed to be significantly negative, then it is likely that the introduction of the standard would have been abandoned even though the particular standard may have been deemed to reflect more accurately particular transactions or events.

Deegan \& Unerman (2011) although many people might argue that accounting regulations just affect how underlying economic transactions and events are reflected in the financial reports, without any impact on the nature or shape of this underlying economic reality, there is a considerable body of evidence which demonstrates that accounting regulations have real social and economic consequences for many organizations and people as well as schools in Kenya.

Berk \& Demarzo (2008) investors, financial analyst, managers and other interested parties such as creditors rely on financial statements to obtain reliable information about a corporation. The main types of financial statements are the balance sheet, the income statement and the statement of cash flows. The balance sheet shows the current financial position (assets, liabilities and stockholders' equity) of the firm at a single point in time.

\subsubsection{Challenges Related to financial controls}

Berk \& Demarzo (2008) argues that the separation of ownership and control creates the possibility of management entrenchment facing little threat of being fired and replaced. Managers are free to run the firm in their own best interests. As a result, managers may make decisions that benefit themselves at investors' expense. No amount of planning and organizing will assure that goals are attained. Control is therefore the essential final step in the management process to ensure that things proceed as planned or the unrealistic plans and targets are revised, where appropriate. As the final step in the management process, controlling provides the critical link back to planning.

Cole \& Kelly (2011) states that the primary aim of the control function of management is to measure performance against aims, objectives and standards with a view of enabling corrective actions to be taken, where necessary to keep plans on course. Control is essentially a question of developing feedback systems throughout the organization by ensuring that there is progress, accurately and deviations if any that need to be made to stay on the course.

Financial control takes the targets of desired performances its standards, then collates information systematically which relates to actual performance (usually on a monthly or four-weekly period basis and identifies the variances between target and actual performance. The primary aims of financial control are to; establish short-term business plans, determine progress towards the achievement of short-term plans, ensure coordination between key areas of the organization, delegate measurable responsibilities to managers without loss of control and provide a controlled flexibility for meeting change in the short-term.

Berk \& Demarzo (2008) laments that most projects require the firm to invest in net working capital where in this case is secondary schools. The main components of net working capital are cash, inventory, receivables and payables. Working capital includes the cash that is needed to run the firm on a day-to-day basis. It does not include excess cash, which is cash that is not required to run the business and can be invested at a market rate. Inventory management; receives extensive coverage in a course on operations management. Nevertheless, it is the firm's financial manager who must arrange for the financing necessary to support the firm's inventory policy and who is responsible for ensuring the firm's overall profitability. Therefore the role of the inventory manager is to balance the costs and benefits associated with inventory, because excessive inventory uses cash, efficient management of inventory increases firm value. There is a need for precautionary balance which is the amount of cash a firm holds to counter the uncertainty surrounding firm's cash flows. These control activities leads us to corporate governance which in this case refers to the system of controls, regulations and incentives designed to prevent fraud from happening.

Boddy (2011) laments that financial control process incorporates four elements; setting objectives or targets, measuring actual performance, comparing this against the standard and taking action to correct any significant gap between the two. Therefore controlling is the counterpart of planning and is the process of monitoring activities to ensure that results are in-line with the plan and taking corrective action if required. The balanced scorecard supplement measures of financial performance with those of customer satisfaction, internal process, and innovation and growth which all play a part in an overall assessment of performance.

Boddy (2011) found out that controls can encourage behavior that is not in the best interests of the organization can encourage people to supply the system with inaccurate information and people will resist controls that they feel threaten their ability to satisfy their needs from work. Therefore financial management in schools is at a crisis and research needed to be carried and help in suggesting strategies for the way forward. 


\subsection{Theoretical Framework}

This study adopted Henri Fayol principles of management which its concepts and principles are common in situations of educational administration in Kenya. Henri Fayol (1841-1925) as cited in Cole \& Kelly (2011) Fayol prefaced his famous definitions of management by stating what he considered to be the key activities of any industrial undertaking. He outlined six such key activities, as follows: technical, commercial, financial, security, accounting and managerial. Fayol explained that the first five were all interdependent to some extent and there was no single one which was concerned with broad planning and resourcing. To manage, said Fayol, is to forecast and plan to organize, to command, to coordinate and control. He saw forecasting and planning as looking to the future and drawing up a plan of action. Organizing is seen in structural terms, and commanding was described as 'maintaining activity among the personnel in Kenyan education system with the accountants, clerks and bursars. Coordinating was seen as essentially a unifying activity controlling meant ensuring that things happen in accordance with established policies and practices. It is important to note that Fayol did not see managerial activities as exclusively belonging to the management. Such are part and parcel of the management. Such activities are part and parcel of the total activities of an undertaking. Having said this, it is equally important to point out that Fayol's general principles of management take a perspective which essentially looks at organizations from the top downwards; in financial management the principal authorizes all the payment. The principles provide a foundation and framework for us to explore the practice of management and analyze organizations. Since no management approach provides universally applicable principles of management, today's managers must take those ideas, from the different approaches which best suit the particular requirements of their culture, school and their job. Using the theory the study sought to unearth the challenges that could hinder desired and targeted outcomes through aspects of authority and accountability amongst day secondary schools in Imenti North District.

\subsection{Conceptual Framework}

Conceptual framework can be identified as a set of broad idea and principles taken from the relevant fields of enquiry and used to structure a subsequent presentation (Kombo \& Tromp, 2006). It is a research tool intended to assist a researcher to develop awareness and understanding of the situation under scrutiny and to communicate it. Based on the theory of management using Fayol principles effective schools mobilize their funds and resources to achieve desired educational outcomes of intellectual and moral excellence.

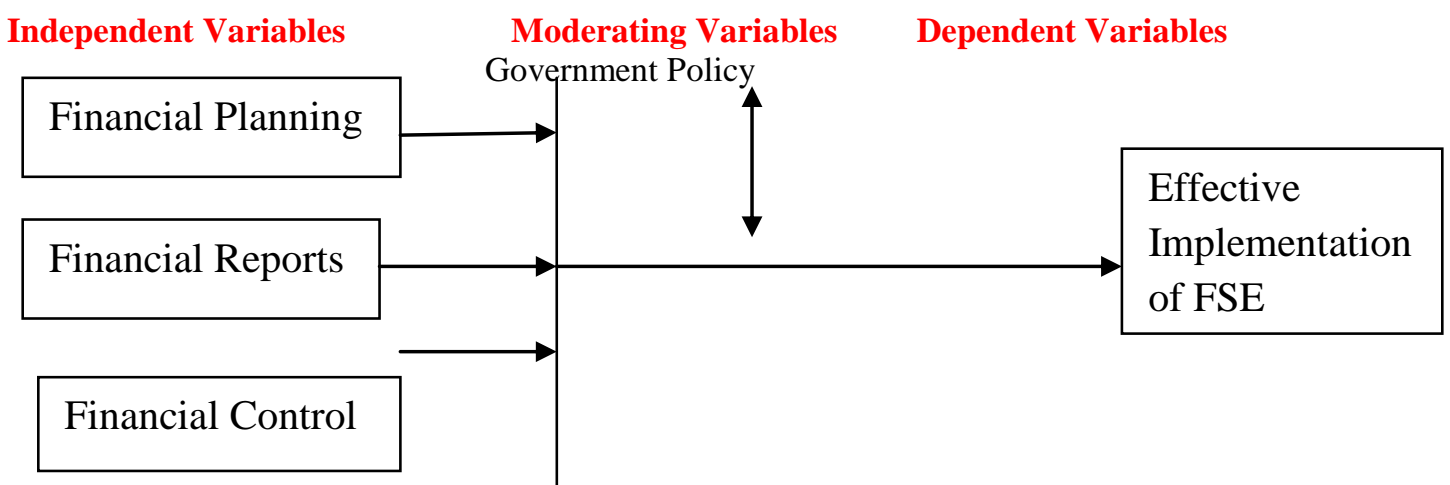

\subsection{Summary of the Chapter}

Figure 2.1 Conceptual Framework

This chapter reviewed independent variables in the aspect of budgeting, accountability, organizing and controlling. When these variables are manipulated through the government policy as the moderating variable, the expected outcome would be successful implementation of FSE. The moderating variables are: government policy and other educational stakeholders who though are not measurable, never the less influences the implementation of FDSE through their financial incentives, legal framework and general policy within which secondary schools in the country operate. If these independent variables are fairly moderated then the program of FDSE can turn out to be effective as intended by the government and the outcome would be increased transition rate, retention, completion and sustainability of students in school.

As long as financial problems will continue to exist, there is need for planning in education to optimize this available information. Therefore there is need of addressing the problem of allocation of funds, budgeting and financial management and how this can be improved for sustainability of the program, hence justification for this study. 


\subsection{Introduction}

\section{METHODOLOGY}

This chapter presents the methodology that was used in order to meet the research objective. According to Mugenda Olive \& Mugenda (1999), research methodology outlines the techniques, methods and tools used in data analysis and how to arrive at the sample size. This chapter presents the procedures that were used to conduct the study, focusing on research design, target population, sampling frame, sample and sampling techniques, research instruments, pilot study, data collection procedure and finally data processing and analysis.

\subsection{Research Design}

This study employed descriptive research design. According to Mugenda Olive \& Mugenda (1999) the purpose of descriptive research is to determine and report the things the way they are. Through this the researcher was able to generalize the findings to present the whole population from the selected sample and in this case the researcher had no control of the variables. The researcher collected and reported things the way they happened without manipulation of any variables.

\subsection{Study Locale}

The study was carried out in day secondary schools in Imenti North District which is in Meru County, Eastern province, Kenya. Imenti North district borders Buuri district to the North, Mount Kenya to the west, Imenti central to the South and Tharaka to the East (G.O.K. 2012). It comprises of two divisions: Miriga Mieru West and Miriga Mieru East covering an area of $223659 \mathrm{~km}^{2}$ (C.B.S. 2009). It has a total of 26 day secondary schools. Singleton, (1993) advises that the ideal setting for any study should be easily accessible to the researcher and should be that which permits instant rapport with the informants. Imenti North district has not fully absorbed FDSE as a strategy to increasing enrolment rates to secondary education and increased literacy levels; therefore the researcher felt that there was need to carry out research in this area.

\subsection{Target Population}

Borga \& Gall (1989) defines target population as all the members of a real or hypothetical set of people, events or objects to which a researcher wishes to generalize the results of the research study. The target population for this study was 26 day secondary schools in Imenti North District. All the 26 head teachers/principals in these day schools, 390 BOG members, and 311 PTA members, The DEO Imenti North District and the two ZQASOs MMW and MME were among the targeted population.

Table 3.1 Target Population

\begin{tabular}{|l|l|}
\hline Category & Target Population \\
\hline Principals/ head teachers & 26 \\
\hline BOG & 390 \\
\hline PTA & 311 \\
\hline ZQASOs & 2 \\
\hline DEO & 1 \\
\hline Total & $\mathbf{7 3 0}$ \\
\hline
\end{tabular}

\subsection{Sample and Sampling Technique}

Sampling means selecting a given number of subjects from defined population as representative of that population. Any statements made about the sample should also be true of the population (Orodho, 2002). This study used area sampling which is a cluster of design where the primary sampling unit represents a cluster of units based on geographic area which in this study is Imenti North District.

The sample size was determined through the approach based on precision rate and confidence level by the following formula:

$\mathrm{n}=\frac{\mathrm{z}^{2} \mathrm{pq}}{\mathrm{e}^{2}}$

where $\mathrm{p}=0.5$

$$
\mathrm{q}=1-0.5
$$

at $95 \%$ confidence level, probability $=\mathrm{z}=1.96$ as per table of area under normal curve for the given confidence level of $95 \%$

$\mathrm{e}=0.05$ since the estimate value should be within $5 \%$ of true value

Substituting $\mathrm{n}=1.96^{2} \times 0.5 \times 0.5=384.16$

$$
0.05^{2} \approx 384
$$

This sample size of 384 was adjusted through the formula in regard to target population. $\mathrm{n}=$ n 


$$
\mathrm{n}=\frac{1+\mathrm{n} / \mathrm{N}}{\frac{384}{1}+384 / 730 \approx 250}
$$

To determine the size of each category of respondent the researcher worked as follows: $\underline{390} \times 250=133$ (BOG members)

730

$\underline{311} \times 250=106$ (PTA members)

730

$\underline{26} \times 250=8$ (Principals)

730

Gay (1992) recommends that when the target population is small (less than 1000 members), a minimum sample of $20 \%$ is adequate for educational research. From the 730 members of the target population, the researcher adjusted this number to 250 participants which formed $34.25 \%$ of the target population, which was in line with Gay’s (1992) recommendation for a small population less than 1000 members.

Table 3.2 Sampling Frame

\begin{tabular}{|l|l|l|}
\hline CATEGORY & TARGET POPULATION & SAMPLE SIZE \\
\hline Head teachers/principals & 26 & 8 \\
\hline BOG & 390 & 133 \\
\hline PTA & 311 & 106 \\
\hline ZQASOs & 2 & 2 \\
\hline DEO & 1 & 1 \\
\hline Total & $\mathbf{7 3 0}$ & $\mathbf{2 5 0}$ \\
\hline
\end{tabular}

\subsection{Research Instruments}

The questionnaires were given to the BOG and PTA members. Questionnaires were justified since respondents had time to give well thought out answers and large samples were made use of and thus the results were made more dependable and reliable. Questionnaires had neither names of the respondents no mention of the schools which participated, therefore in this case it was maintained that respondents had freedom to make their suggestions and express their views without fear of intimidation. Questionnaires contained background information of the respondents, and subsequently there were questions on the independent variables of the study. These questions were addressing financial management challenges facing implementation of FDSE in Imenti North District, in relation to financial planning, reports and controls.

Interview schedules were used to guide the researcher on conducting research with the DEO, ZQASOs and the principals on financial management challenges facing implementation of FDSE in Imenti North District. The researcher used interview schedule because they were very useful in extensive enquiries and led to fairly reliable results and more information and that too in greater depth was obtained.

\subsubsection{Reliability of measuring instruments}

Kothari, (2011) defines instrument reliability as the ability of a measuring instrument to provide consistent results. Reliable measuring instrument does not contribute to validity, but a reliable instrument need not be a varied instrument. Pilot study enabled the researcher to assess the clarity of the questionnaire questions so that modifications were made to improve on the quality of the research instrument hence increasing its reliability. Split-Half technique of reliability testing was employed, whereby the pilot questionnaires were divided into two equivalent halves and then a correlation coefficient for the two halves computed using the Spearman Brown Prophesy Formula as indicated below

$\mathrm{P}^{*} \mathrm{xx}^{\prime}=\underline{\mathrm{NPxx}}$

$1+(\mathrm{N}-1) \mathrm{Pxx}$

Where $\mathrm{N}$ is the number of tests combined

Pxx' is the reliability of the current 'test'

$\mathrm{N}=2$ implies doubling the exam length by adding items with the same properties as those in the current exam.

Simplified as

Reliability of scores on total test $=2$ x reliability for $1 / 2$ test

$1+$ reliability for $1 / 2$ test

A reliability coefficient of 0.67 was obtained which lies within the range recommended by Keiss and Bloomist (1985) a minimum correlation coefficient of 0.65 as indicating that an instrument is reliable. 


\subsubsection{Validity of measuring instruments}

Kothari, (2011) defines instrument validity as the extent to which differences found with a measuring instrument reflect true differences among those being tested. Validity of the instruments was subjective to the opinions and judgments of the researcher. Instrument validity was improved through expert judgment, where the researcher sought assistance of her supervisors who are as experts in research to help in improvement of the instrument validity. After analyzing the results of the pilot study some responses were amended and irrelevant items were discarded and replaced with more useful, relevant and logical ones which elicited the required responses.

\subsection{Pilot Study}

The researcher conducted a pilot study from Imenti central district where 6 head teachers/principals who were not included in the final study population. From these six heads two of their PTA members and two BOG members were selected through simple random sampling method which included the selection of sample members being unbiased and the general acceptance by the layman that the method was fair: for the pilot study. The number of participants was a total of 30 cases, which is the minimum number of cases required for conducting statistical analysis as recommended by Mugenda \& Mugenda (1999). The major reason for conducting the pilot study was to check typical responses to questions and also helped the researcher familiarize with what she expected to encounter during her research in the field and made adjustment and corrections as appropriate.

\subsection{Data Collection Procedure}

The researcher obtained research permit from the Ministry of Education after the proposal was approved by the university. The permit was requested through the DEO Imenti North District to the MOE before the start of the study. A letter of introduction was written explaining the purpose and need for the research. The researcher personally administered the questionnaires to the BOG and PTA members and interviewed the principals, DEO and ZQASOs. The researcher had to book appointments with the principals, DEO and ZQASOs for face to face administering of the interview. Questionnaires were dropped at the respondents schools by the researcher where the researcher discussed with the respondent the duration of filling the questionnaire which was one week to allow well thought answers and the filled-in questionnaires were collected. The respondents were assured that strict confidentiality would be maintained in handling of the responses. The researcher promised to give a copy of the final report as a way of motivating the respondents to fill the questionnaires and to give accurate information to the best of their knowledge.

\subsection{Methods of Data Analysis}

According to Kothari, (2011) the purpose of the coding would be to classify the answer to a question into meaningful categories so as to bring out their essential pattern. Coding refers to the process of assigning numerals or other symbols to answers so that responses can be put into a limited number of categories or classes. After the information was collected, the researcher did data editing which involved the process of examining the collected raw data to detect errors and omissions and to correct these where possible. Data collected was both quantitative and qualitative. Quantitative data was analyzed through creation of simple tables that showed the frequency of occurrence through establishing statistical relationships between variables to complex statistical modeling of both categorical and quantifiable data. On the other hand qualitative data was analyzed through development of data categories, recognizing relationships and testing hypotheses to produce well-grounded conclusions. Results off data analysis were presented in frequency distribution tables, bar graphs and pie charts.

Table 3.3: Data Processing and Analysis

\begin{tabular}{|l|l|l|}
\hline Research Objectives & Types of Data & Statistical Test \\
\hline $\begin{array}{l}\text { To find out ways the role of financial planning in implementation of Free } \\
\text { Day Secondary Education in Imenti North District. }\end{array}$ & Descriptive & $\begin{array}{l}\text { Descriptive statistics } \\
\text { Mean } \\
\text { Mode }\end{array}$ \\
\hline $\begin{array}{l}\text { To assess the input of financial reports on implementation of Free Day } \\
\text { Secondary Education amongst day schools in Imenti North district. }\end{array}$ & Descriptive & $\begin{array}{l}\text { Descriptive statistics } \\
\text { Mean } \\
\text { Mode }\end{array}$ \\
\hline $\begin{array}{l}\text { To establish financial controls on implementation of Free Day Secondary } \\
\text { Education in Imenti North District. }\end{array}$ & Descriptive & $\begin{array}{l}\text { Descriptive statistics } \\
\text { Mean and Mode }\end{array}$ \\
\end{tabular}




\subsection{Introduction}

\section{Data Presentation And Discussions}

This chapter presents analysis of data and the findings of the study. The general objective of the study was to investigate financial management challenges facing implementation of free secondary education amongst day schools in Imenti North district, Kenya. Data will be presented in sections with the first section covering demographic data of respondents, followed by the role of financial planning in implementation of free day secondary education, input of financial reports in management of FDSE and finally financial controls input on implementation of FDSE in Imenti North district.

\subsection{Demographic Data}

This study sought demographic data of the respondents including gender and academic qualifications. This study was carried out in day secondary schools in Imenti North district of Meru County, Kenya.

Table 4.1 Demographic information of respondents

\begin{tabular}{lccc}
\hline Respondents & Male & Female & Total \\
\hline Principals & 5 & 3 & 8 \\
BOG members & 67 & 36 & 103 \\
PTA members & 56 & 30 & 86 \\
ZQASOs & 2 & 0 & 2 \\
DEO & 0 & 1 & 1 \\
\hline Total & $\mathbf{1 3 0}$ & $\mathbf{7 0}$ & $\mathbf{2 0 0}$ \\
\hline
\end{tabular}

The study had a target population of 730 with a sample size of 250 but there were only 8 principals, 103 BOG members, 86 PTA members, 2ZQASOs and 1DEO who participated in the study, a total of 200 participants which translated as $27.40 \%$ of the target population and $80 \%$ of the sample size. There was uneven distribution of gender participation with Males constituting $65 \%$ and females $35 \%$ of the respondents, and for the principals it was $62.5 \%$ for males and $37.5 \%$ for females.

The study sought to find out academic qualifications of principals, BOG and PTA members in the study and Table 4.1 shows the respondents level of education.

Table 4.2 Academic Qualifications of the Principals, BOG and PTA members

\begin{tabular}{lccc}
\hline Academic Qualifications & Principals & $\begin{array}{c}\text { BOG } \\
\text { Number }\end{array}$ & $\begin{array}{c}\text { and PTA } \\
\text { percentage }\end{array}$ \\
\hline PhD & 0 & 0 & $0.00 \%$ \\
Masters Degree & 3 & 13 & $6.88 \%$ \\
Bachelor's Degree & 5 & 39 & $20.63 \%$ \\
Diploma & 0 & 28 & $14.81 \%$ \\
Certificate Level & 0 & 49 & $25.93 \%$ \\
Secondary 'O' Level & 0 & 60 & $31.75 \%$ \\
\hline Total & $\mathbf{8}$ & $\mathbf{1 8 9}$ & $\mathbf{1 0 0 . 0 0 \%}$ \\
\hline
\end{tabular}

Table 4.2 shows that majority of the principals had Bachelor's Degrees while minority had Masters Degrees. Majority of BOG and PTA members $31.75 \%$ had secondary ' $O$ ' level qualification, followed by $25.93 \%$ who had certificate level qualification, $20.63 \%$ had a Bachelors Degree, $14.81 \%$ had a diploma qualification and only a small number of $6.88 \%$ had a Masters Degree. Implementations of free secondary education for educational and school managers require adequate managerial skills. Educational managers need various skills in order to cope with the demands of their management roles. Such skills can be attained through formal training, and it is encouraging to note that principals had at least Bachelors Degree. Robbins (2003) laments that the skills needed for management can be grouped into three broad categories namely technical skills, human skills and conceptual skills. Technical skills refer to the category of skills which enable the manager to use resources and scientific knowledge and to apply techniques in order to accomplish the objectives of the organization. Human skills refer to the ability to work well with other people and achieve results through them. Conceptual skills refer to the cognitive capacity to perceive the organization in its totality and the relationship between parts thereof. Robbins (2003) further explains that these skills manifest themselves in educational managers being able to analyze and diagnose relatively complicated situations whilst at the same time being able to visualize the interrelationships of various units of an organization. Training of school managers at school level is essential in enabling them to acquire managerial skills and thereby implement educational programs competently. 


\subsection{Role of financial planning in implementation of FDSE}

The first research question sought to find out ways in which financial planning influence effective implementations of Free Day Secondary Education in Imenti North District and its impacts on Free Secondary Education. While conducting research the data collecting instruments which were interview schedules and questionnaires asked the respondents if the government subsidy funds were remitted on time where all respondents responded with a No that these subsidies are always delayed hence interruption of learning. Further the researcher established that funds provided to these schools by the government were not adequate to meet the school needs throughout the year and hence schools had to devise strategies to deal with these inadequacies. Table 4.3 shows the strategies adopted by educational managers to cope with fund inadequacies.

Table 4.3 Strategies employed by educational managers to meet shortfall in funds inadequacies

Strategy Number of respondents Percentage

Subsidize with PTA funds

Seek donor funding

Seek CDF funding

Hold Fundraising

Budget adjustment

Purchase goods and services on credit

Others
189

106

191

146

158

91
$95.94 \%$

$53.81 \%$

$96.95 \%$

$74.11 \%$

$98.98 \%$

$80.20 \%$

$46.19 \%$

It was established that $95.94 \%$ of the respondents indicated that they subsidized government subsidy with PTA funds to carry out their daily management activities, with $53.81 \%$ of the participants having to seek donor funding while $96.95 \%$ had to visit CDF offices to seek for financial support, with $74.11 \%$ holding fundraising and the highest percentage of $98.98 \%$ indicated that they had to adjust their budget to meet their annual requirements, while $80.20 \%$ decided to purchase goods and services on credit and made payment when funds were available and this posed as a challenge as some of the suppliers withdrew their delivery altogether and finally a small percentage of $46.19 \%$ indicated that they used other strategies to cope with fund inadequacies. With these strategies some of the sampled day schools are able to plan and account for their funds hence have built modern science laboratories, dining halls, book stores, administration block among others which come out as the strengths of these schools to compete effectively with boarding schools and produce students who are joining higher institutions of learning. On the other hand, some of the schools sampled do not have even the most basic requirements such as sanitation facilities, kitchen and well built classrooms especially the lower part of the district is under deplorable conditions and not comparable to upper region hence each has unique challenges as geographically located.

The researcher interviewed the DEO and ZQASOs who responded that funds allocated per student per academic year was small compared to the strained budgets these schools are operating in hence insufficient school funds affected Free Day Secondary Education Implementation within the district. The study further found out a few of the schools sampled had complied with service charter in relation to service delivery where they had qualified financial and accounting staff who ensured compliance with laid down systems on procurement regulations and proper utilization of public funds in schools and made them stand out as successful.

According to Lewin (2008) projections of the financing required for a significant expansion of access to secondary education- including towards a basic education cycle of 9 or 10 years indicate that enrolments in secondary education cannot be expanded at the present unit cost levels. Constrained by limited resources and in the absence of significant policy reforms, SSA countries have responded to the increased demand for secondary places by spreading the same resources over larger number of students (Verspoor, 2008). Consequently, essential inputs often are in short supply resulting in increasing class sizes, shortage of textbooks, poorly stocked libraries and double or triple shift use of facilities and even money to sponsor educational managers workshops and seminars which adversely affect the curriculum implementation and follow-up. Finally with lack of public demand for accountability from educational managers is a strong factor for declining quality in the education system.

It transpired from the interviews that while some schools draw up budgets, others do it in a rather careless fashion (e.g. "some teachers are lazy and rely on the budgets of the past years" and "we do it in a very sketchy manner"). The problem pertaining to a lack of funds was common to all the participants. Whereas one said that a lack of funds "makes it difficult to come up with a reliable budget because the school has many requirements", another one mentioned that "we are not able to follow the budget because of lack of funds." The fore quoted two participants suggested that budgeting is a futile exercise because of a lack of funds. The foregoing underlines some of the participants' lack of understanding of the budgeting process. Rather than prioritizing expenditure in a tight budget on the grounds of estimated income and expenditures, a number of 
them abdicated even before trying to draw up a realistic budget (cf. Kruger 2005). This may be attributed to, as surfaced during the interviews, the participants' lack of formal financial management training. All the participants nonetheless mentioned during the interviews that they attended numerous compulsory short inservice workshops on financial management. Even though some of the participants unwittingly acknowledged that their actions were in contravention with the Education Act of 2010, others acknowledged the necessity to involve stakeholders in the budgeting process for the sake of transparency.

It appears from the data analysis that most of the school principals who took part in the study understand and appreciate the involvement of the school board in budgeting. This is highlighted by the following extraction from a participant's narrative: ... the people who are mostly involved in budgeting are the school board; they are even invited to ask the external auditors so that they can explain the budget to the parents.

Even though the school boards are involved in budgeting majority of them lack expertise and skills of financial management. This diverse information on the involvement of stakeholders in the budgeting process also came to the fore in some of the narrations on business education teachers being involved in the process to bring their accounting knowledge into practice.

Most of the participants indicated that parents' involvements in their schools' budgeting are minimal. They attribute this firstly to the existence of school boards. A few of the principals seem to make an effort to ensure that parents understand the situation. One participant specified that "if we have to increase the fees we explain the situation to the parents who normally give us the mandate to make such increments".

\subsection{Financial reports input in management of FDSE}

The second research question sought to assess the financial reports input in implementation of Free Day Secondary Education in Imenti North District. To determine this, interview schedules and questionnaires addressed this research question and the findings are discussed below. Figure 4.q1 below.

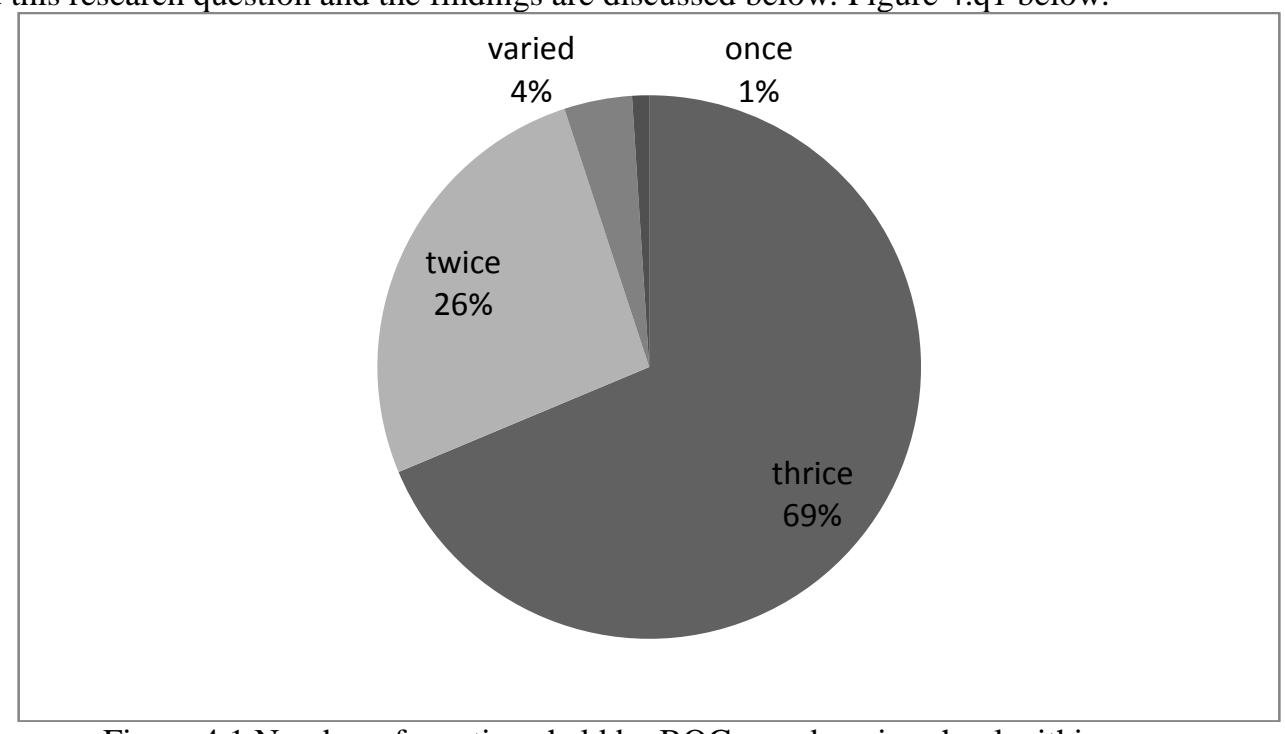

Figure 4.1 Number of meetings held by BOG members in school within a year

It was pointed out that the main duties performed by BOG were; preparation and submission of school revenues and expenditure to the cabinet secretary of education for approval, receiving of grants or grants-in aid from public or local authority funds and administering them to schools in accordance with the approved estimates of expenditure, submission to the cabinet secretary for approval plans for development or promotion of education in the area and carry out the plans if approved, tendering of advice to the cabinet secretary on the establishment of new schools, submission of statistical, financial and other reports as the cabinet secretary may require, superintendent to the management of public schools and fulfillment of other functions as the cabinet secretary may prescribe. With these roles some schools have BOGs which are both effective and efficient in their work, laid down their core values and adhering to them which have made them the envy of district education stakeholders and have attracted sponsors whose work they recognize by writing their names on the structures constructed and officiated for use.

All the principals interviewed said that they also had functional PTAs in their schools. They responded as shown in figure 4.2 


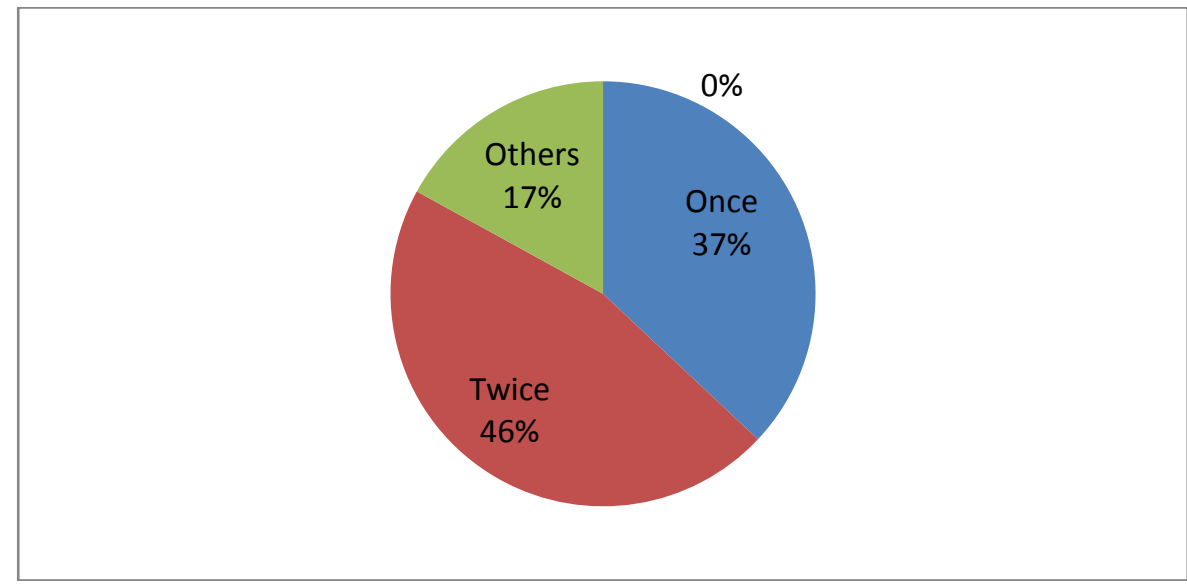

Figure 4.2 Number of meetings held between BOG and PTA members in a term

The content analysis revealed that whereas some of the participants' schools still use outdated hardcopy filings systems (e.g. "we use an old system of cards for individual students' accounts"), others have started to computerized their financial records (e.g. "part of the recording is done on a computer and I think it has made referencing easier"). Most principals however, experience problems with handling receipts. For instance, one principal confessed that "most of the time when I am very busy, I forget to take in the receipts". Another participant indicated that "it is difficult for me to bring things such as the receipts to be recorded, if I am not reminded about it".

Several of the participants mentioned that their schools have no bursars resulting to principals delegating financial management duties to capable teachers. For instance, one participant admitted that "there is no bursar but the school has somebody delegated to put the deposit slips into the student's files". Alternatively, some principals choose to form financial committees responsible for financial management. One participant stated that "I am planning to ask the head of a department to form a small committee who will assist in financial management". By being responsible for financial management and budgeting, these committees report regularly to the principal, who is responsible for financial management and budgeting. At some schools an effort is made to make the financial statement comprehensive especially to the parents which are read during Annual General Meetings. One of the participants indicated that "when we present the financial statement, we try to explain in Kimeru (the local language) everything that has been written in English as most of my parents do not understand English". This ensures that everything in the financial statement is communicated comprehensibly to the parents. In another school the participant pointed out that "when you do the financial statement you make a summary so that parents can understand." The lack of coherence amongst participants on the dissemination of financial information was underlined in their differentiating views on the furnishing of financial reports to stakeholders.

Schools seem to differ in the way they handle financial reporting. Participants of this study apparently report to different stakeholders. For example, one of the participants stated that "a financial report is normally prepared and presented to the church which is the sponsor". It is possible that other parents do not belong to the same church that owns the school, which means that they may not have access to the financial report. Another participant said: "We are encouraged to give financial reports once per term to the parents but parents rejected the idea of giving them". It furthermore surfaced from the interviews that some of the principals are not in favour of the disclosure of financial reports to all stakeholders.

\subsection{The role of financial controls in implementation of FDSE}

The third research question sought to establish the extent to which financial controls influence implementation of Free Day Secondary Education in Imenti North District. Principals were asked to state the number of management courses they had attended in the previous two years, of which they responded as shown in figure 4.3 below. 


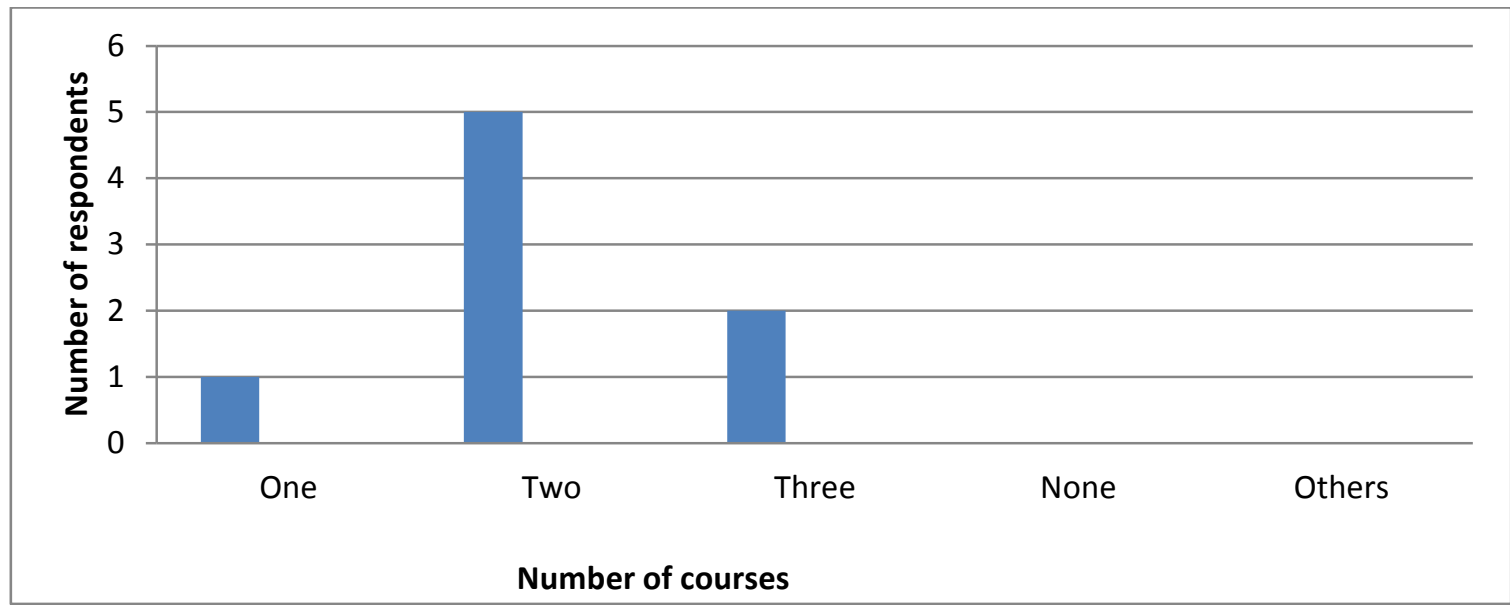

_ Figure 4.3 Number of training courses attended by principals in the two preceding years

Table 4.4 Number of financial management trainings attended by BOG and PTA members between January 2011 and June 2013

\begin{tabular}{lcl} 
Number of education & Number of respondents & Percentage \\
\cline { 1 - 2 } Management trainings & & \\
One & 36 & $19.05 \%$ \\
Two & 25 & $13.23 \%$ \\
Three & 16 & $8.46 \%$ \\
Four & 4 & $2.12 \%$ \\
None & 108 & $57.14 \%$ \\
Others (Specify) & 0 & $0.00 \%$ \\
\hline Total & $\mathbf{1 8 9}$ & $\mathbf{1 0 0 . 0 0 \%}$ \\
\hline
\end{tabular}

Table 4.5 Principals qualifications influence in implementation of FDSE

\begin{tabular}{lcccc}
\hline Extent & Number of respondents & \multicolumn{2}{c}{ Percentage } & \\
Not at all & & 9 & $16.40 \%$ & \\
Little extent & 31 & & \multicolumn{2}{c}{$23.28 \%$} \\
Moderate extent & & 44 & $43.39 \%$ \\
Great extent & 82 & & $12.17 \%$ \\
Very great extent & 23 & $\mathbf{1 0 0 . 0 0 \%}$ \\
\hline Total & $\mathbf{1 8 9}$ & & \\
\hline
\end{tabular}

From the above findings it shows that rating are distributed to all the values but varying from one aspect to the other such that majority at $44.44 \%$ felt that principals had average qualifications required for management, with $29.63 \%$ saying that principals had good qualifications, $17.46 \%$ of the respondents said that principals had excellent qualifications, while $6.35 \%$ indicated that they had poor qualifications and a small percent of $2.12 \%$ of the respondents felt that principals had very poor qualifications for management. Finally both groups were asked to rate other aspects of qualifications that affected implementation of FDSE and they said from teaching role to management role affected to a great extent, management skills and expertise were of great extent but lacking, information technology competence was moderately affecting the program, creativity and innovativeness were at great extent affecting the program. Furthermore, there are specific skills and competencies that good educational managers, regardless of the specific position possess. They also need organization as a necessary skill for building of a program and finally must have or develop strong communication skills. Some of the schools have been able to properly utilize the school resources that is both capital and human through establishment of learning and teaching facilities which has led them to attracting large number of students who have to walk for kilometers to such schools whereas others are operating on very small numbers of students such as less than twenty in a class, which is associated with the management in these schools.

From the data analysis this study established that it is difficult for schools to operate because school fee payments are not made in time or not paid at all. Principals however, have different perceptions regarding the problem and thus handle the matter differently. As a result of poverty, parents seem to struggle with school fees payments and mostly pay late. In one school the principal reported that "parents are struggling to pay the school 
fees and it is the policy of the school not to send students home because of a failure to pay". This participant shows empathy for poor students and had to use money from their pockets for school activities. One of the other participants said that he takes a hard line on non-payment and routinely expels students whose parents are not willing or able to pay school fees.

The data revealed that principals experienced the following problems regarding the system whereby students pay school fees at the banks: banks often delay making monthly bank statements available for the schools; students do not always bring the bank slips on time; and bank charges are very high for such schools to maintain. These have adverse effects on reconciling the bank statements. One of the participants indicated for instance that "the bank delays giving us the bank statements and therefore we cannot reconcile statements". In the same vein, another participant had the following to say: "You can do the bank reconciliation statement but in most cases it may not balance because some students will still not have submitted the bank slips". It is thus difficult for the school to know exactly how much money it has in the bank at any given point in time.

In their discussions on aspects of financial control participants emphasized the importance as well as problems pertaining to auditing. Only some schools carry out internal auditing others have to wait for external auditors from the MOE. One of the participant specified that "we do internal auditing, but never show it to anybody". Another participant said: "... for me, it is a lot of work; it's a double job if I also have to do it internally. So I give everything to them to do". In another school the participant indicated that "there has not been any auditing in this school to date, but arrangements are being made to audit accounts". Even though auditing was not done, this principal acknowledges the necessity of auditing as an integral part of sound financial management Although most of the participants acknowledged the importance of auditing, only a few of them mentioned that their schools carry out auditing on a regular basis.

\subsection{Introduction}

\section{Summary, Conclusions And Recommendations}

This chapter presents the research findings summary, then conclusions derived from the research findings summary, the recommendations which are drawn from the conclusion and finally recommendations for further research.

\subsection{Summary of main findings}

This study was to investigate financial management challenges facing implementation of Free Secondary Education amongst day schools in Imenti North District, Meru County, Kenya.

Chapter one presents the background to the study which focuses on government funded education from a financial management perspective. The background tries to explain the cause roots of these challenges in relation to the variables identified. The statement of the problem, this study sought to find out why implementation of Free Secondary Education amongst day schools in Imenti North District has not achieved the targeted educational goals and objectives which were laid down. The general objective of the study was to investigate financial management challenges facing implementation of Free Day Secondary Education program and to evaluate their effectiveness in meeting requirements of the educational goals. The specific objectives and research questions were to find out management challenges facing educational managers in relation to; financial planning, financial reports and financial control role in implementation of Free Day Secondary Education. Justification of the study entails valuable insights to the educational stakeholders, the scope of the study cites the geographical area of the study and the final section presents the limitations of the study.

Chapter two provides a review of related literature to the study. The reviewed literature covered the status of secondary education in Kenya, management challenges related to introduction of Free Secondary Education in relation to financial planning, financial reports and financial controls. Later there was development of theoretical framework, conceptual framework and finally summary of the chapter.

Chapter three dealt with methodology used in the study. This chapter looked at the research design, study locale, target population, sample and sampling technique and the sampling frame. This chapter further looked at the research instruments, pilot study and measurement of testing instruments validity and reliability. Data collection procedures and methods of data analysis are finally discussed in chapter three.

Chapter four covers data presentation, analysis and interpretation. Education in Kenya is largely financed by the government through provision of tuition, administration costs, school maintenance and improvements and class activities. However, parents are responsible for provision of uniforms, school meals and transport of their children. It was established that when secondary education is made free, gross enrolment rates are increased. However, there is a likelihood of education quality being compromised if all other factors are not adequately dealt with. The study was based on a general objective which was to investigate financial management challenges facing implementation of FSDE program; and to evaluate their effectiveness in meeting requirements of the educational goals and aims, particularly in Imenti North District, Meru County Kenya. The 
study was conducted in day secondary school in Imenti North district with permission through the DEO's office. Data was collected from 8 principals, 103 BOG and 86 PTA members, 2 ZQASOs and 1DEO.

All the participants reported that government funds are not remitted on time and all the schools had devised strategies to cope with such delays. They also indicated $100 \%$ that these delays influenced implementation of FDSE and the funds provided by the government were inadequate to meet school needs throughout the year. It was noted that $98.8 \%$ had to adjust their budget, $96 \%$ subsidized with PTA funds, $97.2 \%$ sought CDF funding, $80 \%$ purchased goods and services on credit, $74 \%$ held fundraising while $54 \%$ opted to seek donor funding and $46 \%$ used other strategies to cope with inadequacy.

Subsequently it was found out that all schools had operational BOG and PTAs which met at least once per term to discuss their managerial responsibilities and affairs.

The study also noted that educational administrators' qualifications influenced FDSE implementation to a great extent at $36.54 \%$ of the sampled participants. Where their level of qualification was rated as good in a scale of 5 at $30 \%$ and a small percent of $2 \%$ as very poor. Financial management in secondary schools is wanting.

\subsection{Conclusions}

From the above summary which is based on the research findings, it can be concluded that Free Day Secondary Education has made a great impact on gross enrolment rates even though with challenges which have affected the sustainability of the program and ability of students to complete the course hence dropping out of the school. The study established that $100 \%$ of the respondents responded that government subsidy funds were not remitted on time and these delays affected educational managers in carrying out their managerial roles in regard to FDSE. The study also established that the government funds were inadequate to meet the school needs throughout the year and the managers devised strategies to cope with the inadequacy.

The second objective was to assess the input of financial reports on implementation of Free Day Secondary Education. The study established that school financial reports are poorly prepared and new strategies need to be devised.

The third objective was to establish the role of financial controls on implementation of Free Day Secondary Education. Findings of this study repudiate the argument that the existence of a financial policy will inevitably lead to sound financial management in Imenti North District day secondary schools. Despite extensive directives by the MOE on financial planning, this study has shown that budgeting is often done in either a careless fashion or not done at all. The main reason for this seems to be lack of funds. The findings furthermore emphasize the minimal involvement of education stakeholders in the budgetary process. This may be attributed to, amongst others, a lack of knowledge and apathy. The lack of involvement may have a negatively impact on transparency and this would create an avenue for unethical practices.

This study has however shown that efforts of the participating principals to adhere to these guidelines are hampered by problems with the collection and recording of school costs which are not paid for by the government, as well as lack of financial management expertise personnel. There are disparities in the way principals communicate financial reports to educational stakeholders and issue financial reports. Whereas the literature emphasizes the importance of financial control, creating a gap which is emphasized by the findings of this study: auditing - if it is done - is done in an arbitrary way.

In essence, planning is done in order to achieve the school's objectives as directed by government policy through the MOE. That said, these objectives may not be achievable if there is no control; therefore, planning and controlling should be interdependently linked.

\subsection{Recommendations from the study}

Based on the analysis of the study from the conclusions which were derived from the summary, the researcher would like to make the following recommendations;

1. It should be noted that formally scrapping fees without a major increase in public financing can have a disastrous impact on quality and is unsustainable. It is necessary therefore whenever the government abolishes fees it should review the revenue and budget and remit these funds on time.

2. The government through the education act can ensure that proper governance of schools and implementation of schools management committees is properly followed up and that educational managers are aware of any change to the field, as well as best practice with regard to education within the field as it is working in Nigeria.

3. There is need for improvement of policy for tracking of resources to ensure proper, adequate and accountable utilization of resources budgeted for education are utilized in the right manner which can be done through external auditing and the services may be outsourced.

4. Schools can invest cash in short-term securities for example treasury bills which are default risk free, very liquid and highly marketable of their cash which is not in immediate use. 
5. The researcher also recommends schools to develop and gain endorsement of a school's electronic funds management policy that would outline decisions made by school council regarding the schools use of electronic funds, the scope of the implementation internal controls required to be implemented, permissions and delegations, retention and storage of documentation.

\subsection{Recommendations for further research}

1. Research to be carried out in order to determine the underlying reasons for the crisis between policy and practice in financial management in secondary schools.

2. A study to be done on impact of government funds remitted to selected universities in Kenya.

3. A study to be carried out to determine strategies being adopted in relation to financial management challenges in education.

\section{Bibliography}

[1]. ACCA F7 (2010) FINANCIAL REPORTING (INTERNATIONAL AND UK STUDY TEXT $4^{\text {th }}$ Edition London; BPP Learning Media Ltd

[2]. Action Aid International (2010), Contradicting Commitments: How the Achievement of EFA is being undermined by the International Monetary Fund (IMF).

[3]. Akampurira, G. B. (1988) Certificate Economics $1^{\text {st }}$ Edition Nairobi: Oxford University Press

[4]. Andre, F. (2004) Business Mathematics \& Statistics $6^{\text {th }}$ Edition Hampshire South-western CENGAGE learning

[5]. Barasa, J.M.N. (2009) Educational Organisation and Management, Nairobi; Jomo Kenyatta Foundation

[6]. Bateman, Thomas, S. and Zeithaml, Carl (1993) Management Functions and Strategy $2^{\text {nd }} \quad$ Edition Boston, MA: Richard D. Irwin

[7]. Berk, J. and Demarzo, P. (2008) Financial Management $3^{\text {rd }}$ Edition New Delhi; Baba Barkhanath Printers

[8]. Bisschoff, T. (1997) Financial School Management Explained. Pretoria: Kagiso Tertiary.

[9]. Boddy, D. (2011) Management An Introduction, $5^{\text {th }}$ Edition England; Pearson Education $\quad$ Limited

[10]. Borg, W. R. \& Gall, M. D. (1989) Education Research An Introduction. $4^{\text {th }}$ edition New York: Longman. University of the Free State. Approach: Learner's Book. Cape Town: NASOU.

[11]. Bururia, E.C. (2010) Challenges Facing Effective Implementation of Free Secondary Education in Public Secondary Schools in Kangundo District, Kenya; Published Med Thesis, Chuka: Chuka University College

[12]. Chapman, S.N. (2006) The fundamentals of production Planning and Control, Pearson Prentice Hall

[13]. Clarke, A. (2007) The Handbook of School Management. Cape Town: Kate McCallum.

[14]. Cole, G. A. (1997) Strategic Management $2^{\text {nd }}$ Edition UK; Tom Renne

[15]. Cole, G.A. and Kelly, P. (2011) Management: Theory and Practice $7^{\text {th }}$ Edition UK; Cengage learning EMEA

[16]. Davies, B. (2004) A strategic approach to finance and budgeting. In: B Davies, J West-Deegan, C. and Unerman, J. (2011) Financial Accounting Theory $2^{\text {nd }}$ European Edition UK; Mc Graw-Hill Higher Education

[17]. Digumarti, B.R. (2009) Quality Education, New Delhi: A.P.H. Publishing CorporationGay,L.R. (1992) Educational Research, Competences for Analysis and Application, Ohio; Charles E. Merill Publishing, Co.

[18]. Glassman and Sullivan (2008) Governance, Management and Accountability in Secondary Education in Sub-Saharan Africa, Secondary Education in Africa (SEIA) Thematic study No.3 Washington DC: World Bank.

[19]. Government of Kenya (2009) Central Bureau of Statistics Abstract, Nairobi: Government Printers.

[20]. Government of Kenya (2012) Imenti North District strategic Plan 2012-2017; unpublished

[21]. Horngren, C.T., Foster, G. and Datar, S. M. (2005) Cost Accounting $11^{\text {th }}$ Edition Harlow: Prentice Hall

[22]. Hoy, W. K. \& Miskel, C. G. (2008) Educational Administration Theory, Research and Practice, 8th Edition, New York: McGrawHill

[23]. Johnson, G., Scholes, K. and Whittington, R. (2006) ‘Exploring Corporate Strategy Enhanced Media Edition', FT Prentice Hall

[24]. Joubert, R., and Bray, E. (2007) Public School Governance in South Africa. Pretoria: Interuniversity Centre for Education Law and Education policy (CELP).

[25]. Keiss and Bloomist (1985) Research Methods, New Delhi: Kul Bhushan Nangia APN Publishing Corporation.

[26]. Kelly, P. P. (2009) 'International Business and Management' Cengage Learning EMEA

[27]. Kombo, K.D. and Tromp, A.L. (2006) Proposal and Thesis Writing: An Introduction, Nairobi: Pauline Publications House.

[28]. Kothari, C.R. (2011) Research Methodology, Methods and Techniques $2^{\text {nd }}$ Revised Edition, New Delhi; New Age International Publishers

[29]. Kruger, A. G. (2005) Efficient Financial Management. In: I Van Deventer, AG Kruger (Eds.): An Educator's Guide to School Management Skills. Pretoria: Van Schaik, pp. 233-245.

[30]. Kunwar, D., Sing Nyandemo, S. M. (2007) managerial Economics Theory Application $2^{\text {nd }}$ Edition Nairobi: Richmond Designers \& Printers

[31]. Lewin, K.M. (2008) Strategies for Sustainable Financing of Secondary Education in Sub-Saharan Africa, Washington, D.C.: World Bank

[32]. Martin, J. and Fellenz, M. (2010) Organizational Behaviour and Management $4^{\text {th }}$ Edition $\quad$ Cengage Learning EMEA

[33]. McLancy, E. (2006) Business Finance: Theory and Practice $7^{\text {th }}$ Edition, Financial Times Prentice Hall

[34]. Ministry of Education (2010) Implementation Report, Nairobi: Government Printer

[35]. Ministry of Education (2012) Report of the Task Force on Implementation of FSE, Nairobi, MOE

[36]. Mugenda, O. \& Mugenda, A. (1999) Research Methods: Qualitative and Quantitative Approaches, Nairobi: Acts Press

[37]. Ntseto, V. E. (2009) A Programme to Facilitate Principals' Financial Management of Public Schools. Ph.D. Thesis, Unpublished. Bloemfontein: University of the Free State.

[38]. Okumbe, J.A. (2001) Human Resource Management, An Educational Perspective. Nairobi: Educational Development and Research Bureau.

[39]. Orodho J.A. (2002) Techniques of Writing Research Proposals and Reports in Education and Social Sciences, Nairobi: Masola Publishers.

[40]. Robbins, S.P. (2003) Organisational Theory: New Jersey: Prentice Hall.

[41]. Simons, R. (2000) 'Performance Measurement and Control Systems for Implementing Strategy', New Delhi; Prentice Hall

[42]. Singleton, R. A. (1993) Approaches to Social Research, New York. Oxford University Press 
[43]. Stephen, N. M. Nzuve (2007) Elements of Organizations Behaviour Nairobi: Nairobi University Press

[44]. The Daily Nation Newspaper, Friday $15^{\text {th }}$ June 2012, No. 17247: Nairobi, Nation Media Group Limited.

[45]. Varian, H. R. (1993) Intermediate Micro-economics $3^{\text {rd }}$ Edition New York: Narton \& Company

\title{
APPENDIX A LETTER OF INTRODUCTION
}

\author{
BEATRICE NGATU KAGURI \\ P.O. BOX 993-60200 \\ MERU. \\ DATE
}

Dear Sir/Madam,

\section{RE: LETTER OF INTRODUCTION FOR DATA COLLECTION INSTRUMENTS}

This is to inform you that I am a Masters of Business Administration student in Meru University of Science \& Technology carrying out an academic research study focusing on "Financial Management Challenges Facing Implementation of Free Secondary Education in Imenti North District, Meru County, Kenya."

Upon the completion of the research, I presume the findings will provide valuable insights to the government, Ministry of Education, School Principals and the Community at large towards effective management of Schools. Your input will highly contribute to the success of this research.

Attached please find a questionnaire that kindly requests you to provide answers to the questions as precisely and honest as possible. Information collected will be treated with utmost confidentiality. Please do not write your name or that of your school anywhere on the questionnaire. Thank you in advance.

\section{Beatrice Ngatu Kaguri,}

\section{0 \&0720974548}

\begin{tabular}{|c|c|c|c|}
\hline \multicolumn{4}{|c|}{$\begin{array}{l}\text { APPENDIX B } \\
\text { Work Plan }\end{array}$} \\
\hline ACTIVITY & DURATION & MONTH & PARTICIPANTS \\
\hline $\begin{array}{l}\text { Identification of research topic, } \\
\text { and drafting of the abstract }\end{array}$ & Two months & May and June 2012 & Researcher \\
\hline $\begin{array}{l}\text { Proposal development by } \\
\text { outlining the paper in detail. }\end{array}$ & One month & July 2012 & $\begin{array}{l}\text { Researcher guided by the } \\
\text { supervisors }\end{array}$ \\
\hline $\begin{array}{l}\text { Proposal development of final } \\
\text { copy by writing full draft with } \\
\text { all chapters complete }\end{array}$ & One month & August 2012 & $\begin{array}{l}\text { Researcher guided by the } \\
\text { supervisors }\end{array}$ \\
\hline Concept paper presentation & One day & $\begin{array}{l}11^{\text {th }} \text { September } \\
2012\end{array}$ & Researcher \\
\hline $\begin{array}{l}\text { Proposal development by } \\
\text { writing full draft }\end{array}$ & 4 months & $\begin{array}{l}\text { October } 2012 \text { to } \\
\text { January } 2013\end{array}$ & $\begin{array}{l}\text { Researcher guided by the } \\
\text { supervisors }\end{array}$ \\
\hline Proposal presentation & One day & $5^{\text {th }}$ Feb. 2013 & Researcher \\
\hline $\begin{array}{l}\text { Data collection and report } \\
\text { writing }\end{array}$ & 4 months & $\begin{array}{l}\text { April, May and } \\
\text { June }\end{array}$ & $\begin{array}{l}\text { Researcher guided by the } \\
\text { supervisors }\end{array}$ \\
\hline Project report presentation & 1 day & $2^{\text {nd }}$ July 2013 & Researcher \\
\hline
\end{tabular}

APPENDIX C

BUDGET

\begin{tabular}{|l|l|}
\hline Item/activity & Cost in Kenya shillings \\
\hline Stationery & 10,000 \\
\hline Typing and printing & 60,000 \\
\hline Travelling costs & 10,000 \\
\hline Expenses and miscellaneous & 20,000 \\
\hline \multicolumn{1}{|c|}{ Total } & $\underline{\mathbf{1 0 0 , 0 0 0}}$ \\
\hline
\end{tabular}

\section{APPENDIX D}

INTERVIEW SCHEDULE FOR DEO

1. What are your views on the school finances allocated to secondary schools by the government for free secondary education as per student?

2. How has the insufficient school funds affected FDSE implementation in Imenti North District?

3. What is the government policy on budgeting? 
4. Are you involved in school budgeting? If yes. What are your positive and negative experiences of budgeting?

5. Do you receive school financial statements? How often does this happen?

6. How often is school auditing done in your district?

7. What are your views on financial management in implementation of FDSE in the District?

8. In what ways is education stakeholders in financial management committed towards FDSE implementation in rural areas?

9. What proposals would you make to these stakeholders of FDSE to make FSE success full in Kenya?

\section{APPENDIX E \\ INTERVIEW SCHEDULE FOR ZQASOs}

1. Which educational areas are you responsible for?

2. What are your views on the school finances allocated to secondary schools by the government for FSE as per student?

3. What are the impacts of school tuition waiver as per student have on implementation of FDSE in your Zone?

4. What is the government policy on budgeting?

5. Are you involved in school budgeting? If yes. What are your positive and negative experiences of budgeting?

6. Do you receive school financial statements? How often does this happen?

7. How often is school auditing done in your Zone? Explain

8. What are your views on financial management in implementation of FDSE in your zone?

9. In what ways is education stakeholders in financial management committed towards FDSE implementation in rural areas?

10. What proposals would you make to these stakeholders of FDSE to make FSE success full in Kenya?

INTERVIEW SCHEDULE FOR PRINCIPALS

2. $\quad$ Age Bracket

Male [ ]

Female [ ]
a. Under 35 years
b. $35-40$ years
c. $41-45$ years
d. $46-50$ years
e. 51 years and above

3. Number of experience years in teaching
a. Below 10 years
b. 10-15 years [ ]
c. 15-20 years [ ]
d. 20-25 years [ ]
e. 25 years and above [ ]
4 .Academic Qualifications
[ ] Med [ ] Bed [ ] Dip/Ed

Others (Specify)

I) Number of years in headship.

II) How many financial management training courses have you attended in the last two years?

a. One [ ]

b. Two [ ]

c. Three [ ]

d. None [ ] Others: Specify

4. To what extent do the following aspects of administrators qualifications affect FDSE implementation? Use a scale of 1 to 5 where $1=$ no extent $2=$ little extent $3=$ moderate extent $4=$ great extent and $5=$ very great extent

\begin{tabular}{|l|l|l|l|l|l|}
\hline Aspects of Administrators qualifications & 1 & 2 & 3 & 4 & 5 \\
\hline From teaching role to management role & & & & & \\
\hline Management skills and expertise & & & & & \\
\hline Information Technology competence & & & & & \\
\hline Creativity and innovativeness & & & & & \\
\hline Qualification through seminars and exhibitions & & & & & \\
\hline
\end{tabular}




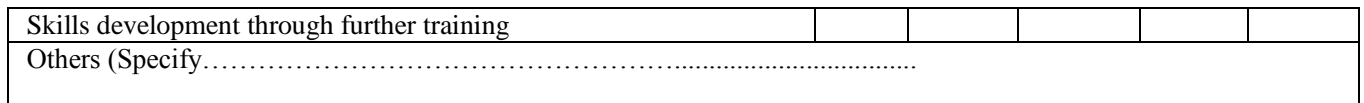

12. Is the government subsidy funds remitted on time?

Yes $\quad[$ ] No n

If No, how do you cope with the delays?

13. Do these delays influence effective implementation of FSDE?

Yes [ ] No [ ]

14. Are the funds provided to your school by the government adequate to meet the school needs throughout the year?

$\begin{array}{llll}\text { Yes } & \text { [ ] } & \text { No } & \text { [ ] }\end{array}$

If No, how do you cope with the inadequacy?

Subsidize with PTA funds [ ]

Seek donor funding

Seek CDF funding

Hold Fundraising

Budget adjustment

Purchase goods and services on credit

Others

(Specify....

9. How do you draw your school budgets?

10. Who do you involve in the budgeting process and why?

i. school board

ii. parents

iii. students

iv. sponsor

v. Others, Specify.

11. How do you control the collection and recording of extra fee charged to students?

12. Which is the accepted mode of fees payment by your students and why?

13. What is the procedure of financial reports preparations?

14. To whom do you present these financial reports and how often?

15. Do you do auditing in your school? If yes, at what intervals?

16. What are your positive and negative experiences of budgeting, financial reports and controls? Briefly describe how you cope with such challenges.

Thank You.

\section{APPENDIX G}

\section{Questionnaire for BOG and PTA Members}

This research questionnaire is aimed at establishing management challenges facing implementation of Free Secondary Education in Imenti North District Kenya. Information provided will be confidential and will be used for academic purposes only and in regard to this do not write your name or that of your school anywhere in this questionnaire. Thank you in advance. Please tick $[\sqrt{ }]$ where appropriate or fill in the required information on the spaces provided.

1. Indicate your gender Male [ ]

2. Are you a BOG or PTA member?
BOG
[ ]
PTA [ ]
[ ]

Female [ ]

3. Age Bracket
(a) Below 20 years
(b) 20-30 years
(c) 31-40 years
[ ]
(d) 41-50 years
(e) 51 years and above
[]

4. Academic Qualifications 
(a) Secondary 'O' Level [ ]

(b) Certificate Level

[ ]

(c) Diploma Level

[ ]

(d) Bachelor Degree

[ ]

(e) Masters Degree

(f) $\mathrm{PhD}$

(g) Other qualification Specify

5. How many educational trainings and seminars on financial management have you attended in the last two years?
(a) One
[ ]
(b) Two
[ ]
(c) Three
[ ]
(d) Four
[ ]
(e) None
[ ]
(f) Others specify

6. To what extent do the following aspects of administrators' qualifications affect FDSE implementation? Use a scale of 1 to 5 where $1=$ no extent $2=$ little extent $3=$ moderate extent $4=$ great extent and $5=$ very great extent

\begin{tabular}{|c|c|c|c|c|c|}
\hline Aspects of Administrators qualifications & 1 & 2 & 3 & 4 & 5 \\
\hline From teaching role to management role & & & & & \\
\hline Management skills and expertise & & & & & \\
\hline Information Technology competence & & & & & \\
\hline Creativity and innovativeness & & & & & \\
\hline Qualification through seminars and exhibitions & & & & & \\
\hline Skills development through further training & & & & & \\
\hline Others $($ Specify............................. & & & & & \\
\hline
\end{tabular}

13. Is the government subsidy funds remitted on time?
Yes
[ ]
No

If No, how do you cope with the delays?

14. Do these delays influence effective implementation of FDSE?
Yes
[ ]
No
[ ]

15. Are the funds provided to your school by the government adequate to meet the school needs throughout the year?

Yes [ ] No N ]

If No, how do you cope with the inadequacy?

Subsidize with PTA funds

Seek donor funding

Seek CDF funding

Hold Fundraising

Budget adjustment

Purchase goods and services on credit

Others (Specify.

9. How do you draw your school budgets?

10 . Who do you involve in the budgeting process and why?

$$
\begin{aligned}
\text { i. } & \text { school board } \\
\text { ii. } & \text { parents } \\
\text { iii. } & \text { students } \\
\text { iv. } & \text { sponsor } \\
\text { v. } & \text { Others, Specify. }
\end{aligned}
$$

16. How do you control the collection and recording of extra fee charged to students?

17. Which is the accepted mode of fees payment by your students and why?

18. What is the procedure of financial reports preparations?

19. To whom do you present these financial reports and how often? 
20. Do you do auditing in your school? If yes, at what intervals?

16. What are your positive and negative experiences of budgeting, financial reports and controls? Briefly describe how you cope with such challenges.

17. In your view can financial statements provide neutral and unbiased accounts of an entity's performance and position?

THE END!!

THANK YOU! 